Portland State University

PDXScholar

$1-1-2008$

\title{
Nanowire Solar Cell Sensitized with II-VI Quantum Dot Layer
}

\author{
Athavan Nadarajah \\ Portland State University \\ Robert Campbell Word \\ Portland State University \\ Kaitlyn VanSant \\ Portland State University \\ Rolf Könenkamp \\ Portland State University, rkoe@pdx.edu
}

Follow this and additional works at: https://pdxscholar.library.pdx.edu/phy_fac

Part of the Physics Commons

Let us know how access to this document benefits you.

\section{Citation Details}

Nadarajah, A., Word, R., VanSant, K., and Könenkamp, R. Nanowire Solar Cell Sensitized with II-VI Quantum Dots. Mater. Res. Soc. Symp. Proc. Vol. 1080 - 015-23 (2008)

This Citation is brought to you for free and open access. It has been accepted for inclusion in Physics Faculty Publications and Presentations by an authorized administrator of PDXScholar. Please contact us if we can make this document more accessible: pdxscholar@pdx.edu. 


\title{
Nanowire Solar Cell Sensitized with II-VI Quantum Dot Layer
}

Athavan Nadarajah, Robert C. Word, Kaitlyn VanSant, and Rolf Könenkamp

Physics, Portland State University, Portland, OR, 97201

\begin{abstract}
We report first results on a new solar cell consisting of a p-i-n hetero-junction formed between $\mathrm{n}$ type transparent nanowires, undoped semiconductor quantum dots and a wide bandgap p-type polymer layer. The overall structure is $\mathrm{SnO}_{2} / \mathrm{ZnO} / \mathrm{CdSe} / \mathrm{MEH}-\mathrm{PPV}$ with $\mathrm{MEH}-\mathrm{PPV}$ standing for poly[2-methoxy-5-(2'-ethyl-hexyloxy)-1,4-phenylene vinylene]. Microscopic studies on the structure of the quantum dot layer before and after anneal indicates a morphology change from a quantum dot assembly to a continuous polycrystalline thin film. The charge transfer between the absorber layer and the adjacent layers is improved as the layer is converted from the quantum dot assembly towards a polycrystalline thin film structure. In optimized devices the spectral photocurrent response shows contributions from the $\mathrm{ZnO}$, the CdSe and the MEH-PPV, covering the spectral range from 300 to $700 \mathrm{~nm}$ with an external quantum efficiency between 30 and $40 \%$. The overall energy conversion efficiency approaches $1 \%$.
\end{abstract}

\section{INTRODUCTION}

Nanostructured solar cells have recently attracted considerable interest as they offer enhanced interface areas for carrier separation, improved optical light trapping and very simple fabrication procedures (1). Incorporation of nanowires into these devices holds promise to improve the charge carrier transport for at least one carrier type. Molecular dye layers, polymers and ultrathin inorganic semiconductor layers have been considered as suitable absorber materials for these cells (2-6).

Here we report on a new solar cell structure which uses a thin quantum dot layer as the precursor for the optically active absorber material. Depending on processing conditions this layer can be designed to have quantum dot character or, alternatively, it can be converted into a continuous poly-crystalline thin film. The absorber layer is deposited on n-type vertically oriented nanowires, which provide a fast electron pathway to the $\mathrm{SnO}_{2}$ substrate. The p-type contact is a polymeric hole conductor, MEH-PPV, and an evaporated Au layer. The deposition processes are carried out at temperatures below $100 \mathrm{C}$, but a number of intermittent annealing steps are provided at temperatures between $100 \mathrm{C}$ and $400 \mathrm{C}$. While the quantum dot layer shows quantum confinement properties in the as-grown state and after moderate anneal, exposure to high temperatures converts the quantum dot layer into to a continuous, polycrystalline thin film with bulk-like properties. In the latter case the confinement effects are found to be absent in the solar cell characteristics. These results show that the quantum dot layer can be used as a useful precursor to obtain conformal film coverage in deep nanostructures. The solar cell efficiency is highest for continuous thin film layers due to the more efficient charge transfer. 


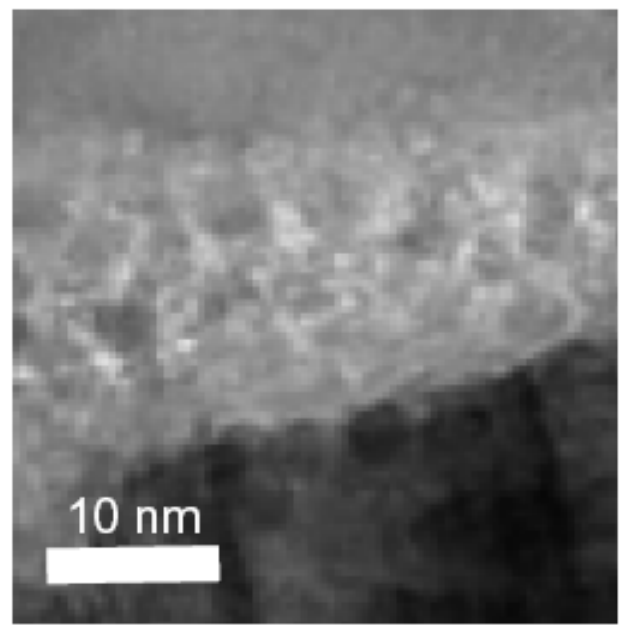

a)

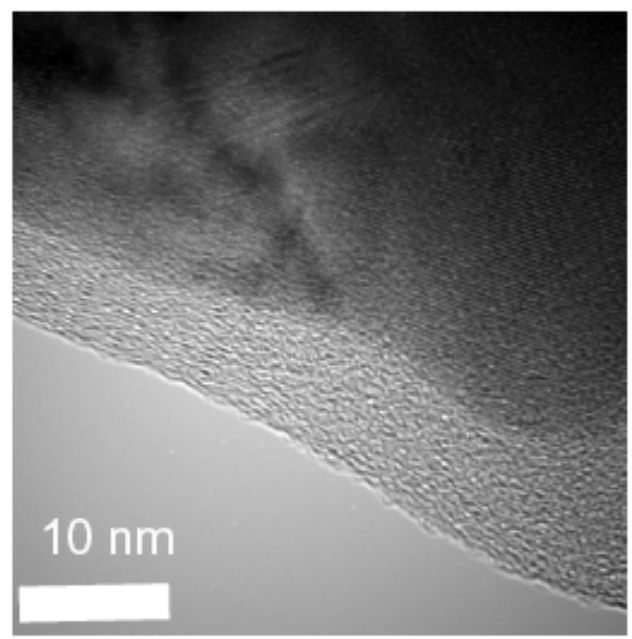

c)

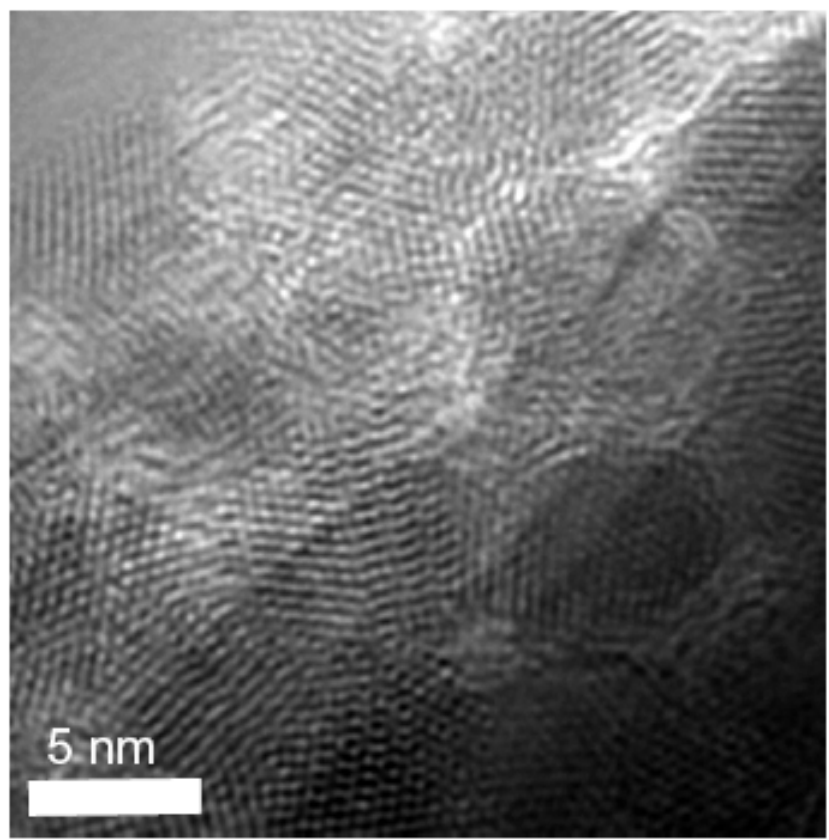

b)

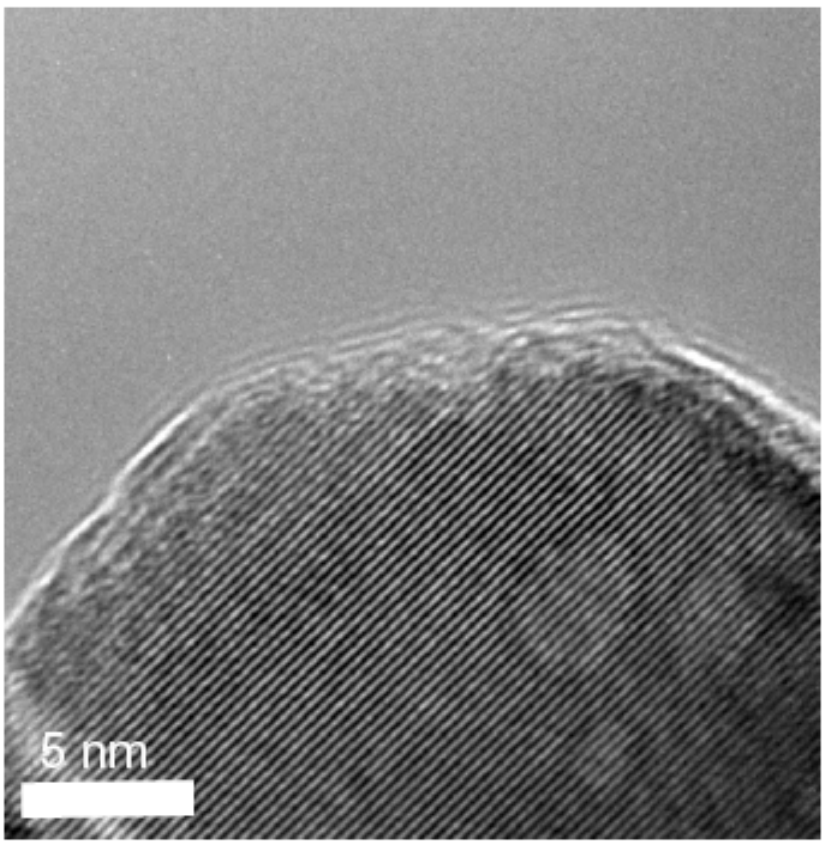

d)

Figure 1 a: CdSe quantum dot layer after deposition. Single quantum dots are visible in the TEM micrograph; b: high resolution micrograph showing crystallinity of single quantum dots with average size of $\sim 7 \mathrm{~nm}$, corresponding to their size in the colloidal solution; c: conformal coverage exhibit by quantum dot layers after annealing at $380 \mathrm{C}$ in $\mathrm{CdCl}_{2} ; \mathrm{d}$ : high resolution micrograph after $24 \mathrm{~h}$ anneal. The crystallite size is now larger than $100 \mathrm{~nm}$. The location of the crystallite is near the nanowire tip. 


\section{EXPERIMENT}

$\mathrm{ZnO}$ nanowires were grown on fluorine doped $\mathrm{SnO}_{2}$ substrates in electrodeposition at 90C using a standard 3-electrode electrochemical cell with $\mathrm{Pt}$ counter and $\mathrm{Ag} / \mathrm{AgCl}$ reference electrodes. Before deposition the substrates were cleaned ultrasonically in acetone and methanol with subsequent rinsing in $\mathrm{HNO}_{3}$ and destilled $\mathrm{H}_{2} \mathrm{O}$. The deposition used aqueous solutions of $0.1 \mathrm{M} \mathrm{KCl}$ and $0.3 \mathrm{mM} \mathrm{ZnCl}$ saturated with $\mathrm{O}_{2}$ gas. Al doping was provided by addition of $\mathrm{AlCl}_{3}$ to the solution. More details on the deposition process are given in ref. 7 . The nanowires were typically $1-2 \mu \mathrm{m}$ long, $100-200 \mathrm{~nm}$ in diameter and their orientation was within $+/-30^{\circ}$ from the substrate vertical. CdSe quantum dots capped with various organic ligands were obtained commercially and dissolved in toluene at a concentration of $2 \mathrm{~g} / \mathrm{l}$. The quantum dot solutions were drop coated in a sequence of 2-4 depositions, and annealed in a mixture of air and $\mathrm{CdCl}_{2}$ vapor at temperatures of $380 \mathrm{C}$ for durations from $30 \mathrm{~min}$ to $30 \mathrm{~h}$. The $\mathrm{CdSe} / \mathrm{ZnO}$ heterostructures were then provided with a p-type contact consisting of a thin MEH-PPV layer and an evaporated Au contact. The completed devices were annealed in vacuum for 5-8 h at $125 \mathrm{C}$.

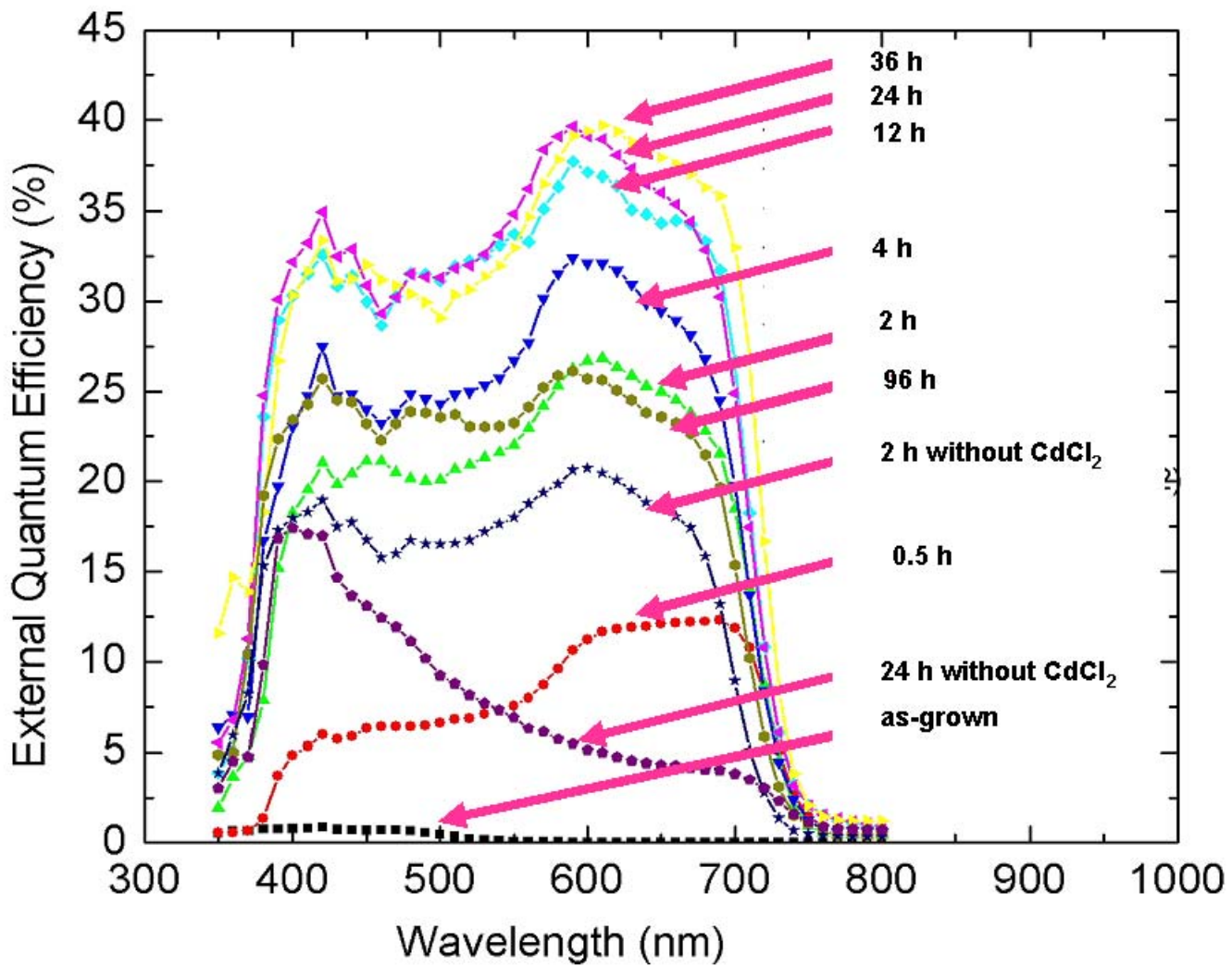

Figure 2: Improvement of solar cell performance with increasing anneal time for annealing at $380 \mathrm{C}$ in air/ $\mathrm{CdCl}_{2}$. The effects of annealing in air only are also shown. 
The annealing in air/ $\mathrm{CdCl}_{2}$ liberates the freshly deposited CdSe quantum dots from their organic ligands and promotes connectivity and grain growth in the particle layer. Depending on the duration of the anneal process the morphology of the quantum dot layer can be changed from that of a loosely connected particle arrangement to a continuous polycrystalline film with micrometer grain size. The polycrystalline films are also observed to be in conformal contact to the nanowires. Fig. 1 shows transmission electron micrographs of this morphology change. The micrographs show quantum dots of $7 \mathrm{~nm}$ average diameter in Fig. 1a-b, and a polycrystalline film in part c-d.

\section{DISCUSSION}

The photo-electrical characteristics of this device directly reflect the morphological changes shown in Fig. 2. The external quantum efficiency curves show very inefficient charge transfer when no annealing is carried out, indicating that the organic ligands block electron injection into the $\mathrm{ZnO}$ and most likely also the hole injection into the MEH-PPV. For extended anneal times the response increases markedly, as shown in Figure 2. The photocurrent onset is universally observed at a wavelength of $730 \mathrm{~nm}$, corresponding to the bandgap of bulk CdSe. For these bulk-like absorber films the cell efficiency is optimal and reaches $1 \%$ for illumination at an intensity of $85 \mathrm{~mW} / \mathrm{cm}^{2}$ with a quartz-halogen spectrum. The open-circuit voltage in these conditions is $0.52 \mathrm{~V}$ and the short circuit current $5.3 \mathrm{~mA} / \mathrm{cm}^{2}$. Typical current-voltage curves for dark and illuminated conditions are plotted in Fig. 3. The dark characteristics of these devices exhibit excellent rectification with very low leakage currents.

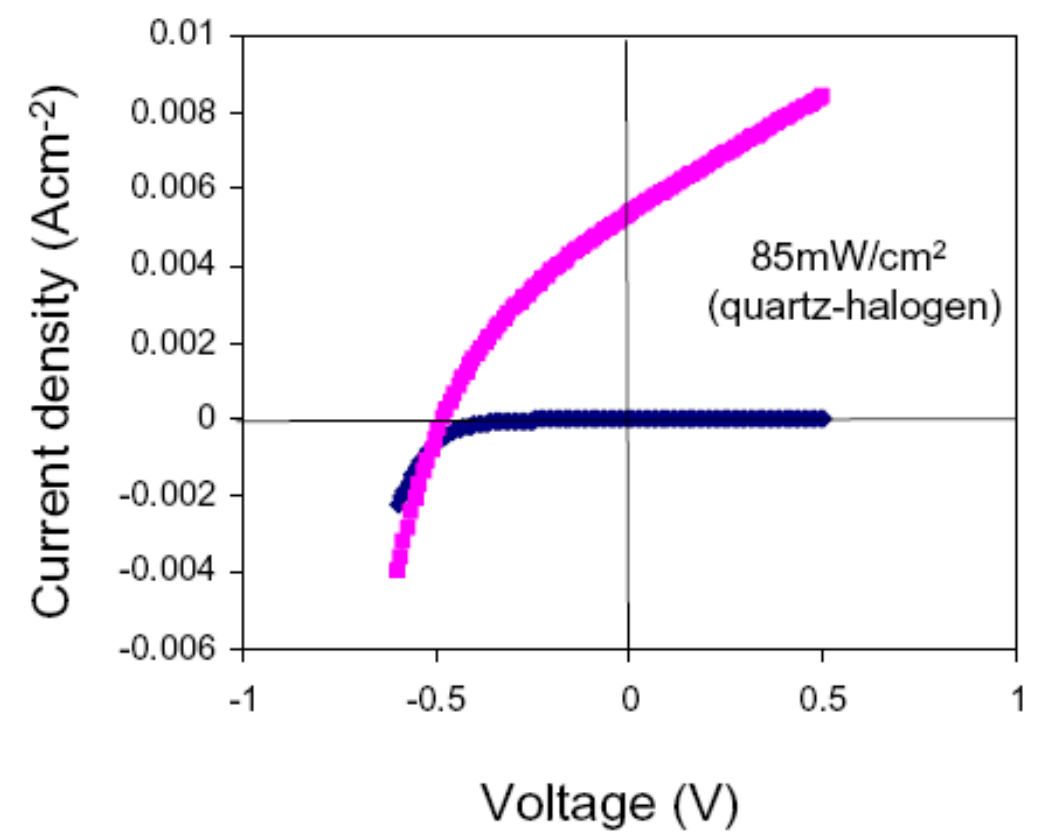

Figure 3: Current-voltage plot of the $\mathrm{SnO}_{2} /$ nanowire $\mathrm{ZnO} / \mathrm{CdSe} / \mathrm{MEH}-\mathrm{PPV} / \mathrm{Au}$ solar cell. 
Finally, in Fig. 4 we show an approximate band diagram of the $\mathrm{ZnO} / \mathrm{CdSe} / \mathrm{MEH}-\mathrm{PPV}$ heterojunction based on energy level values obtained from photoemission spectroscopy. While this diagram does not include band bending, it shows that the electronic levels in the three semiconductors are lined up in a fashion which supports charge separation with electron collection in $\mathrm{ZnO}$ and hole collection in the MEH-PPV layer. More data on doping and Fermilevel position in the various layers need to be known to include band bending and dipole effects at the interfaces.

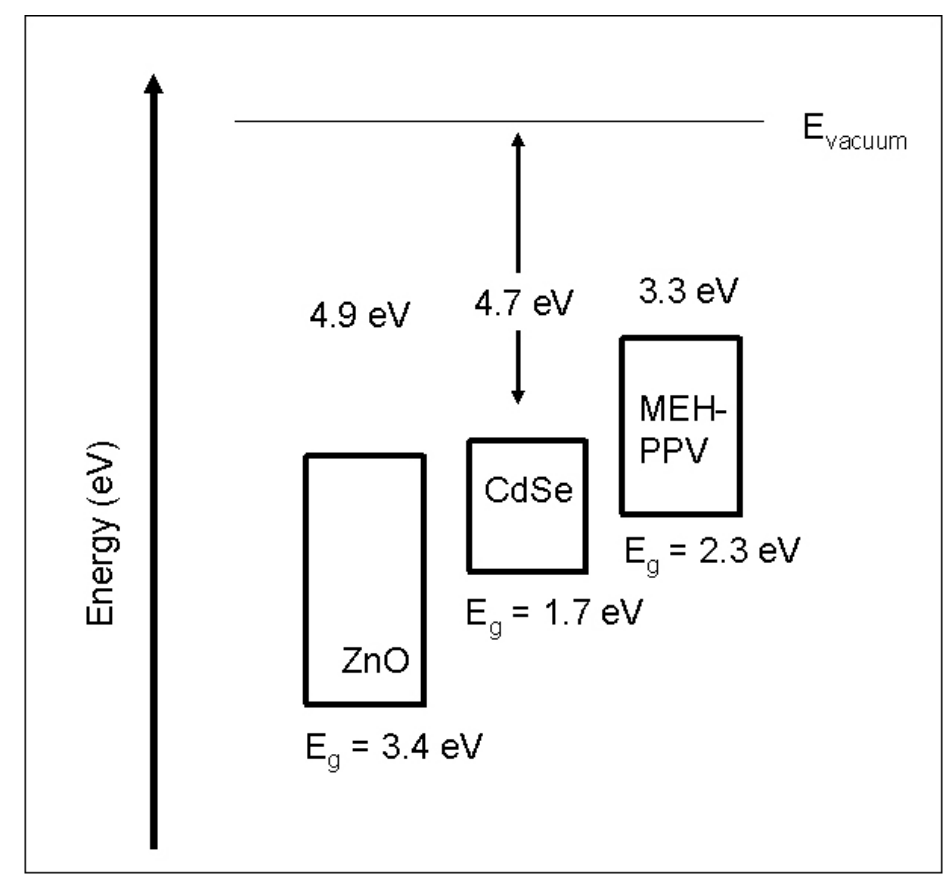

Figure 4: Schematic band diagram of $\mathrm{ZnO} / \mathrm{CdSe} / \mathrm{MEH}-\mathrm{PPV}$ hetero-structure.

\section{CONCLUSIONS}

We have presented a new solar cell consisting of $\mathrm{ZnO}$ nanowires, sensitized by a variety of CdSe thin film arrangements prepared from colloidal quantum dot solutions and contacted by a p-type polymer material. The absorber layer morphology in these devices can be varied from loosely connected quantum dot layers to continuous polycrystalline thin films with excellent surface conformality. Best conversion efficiencies are in the region of $1 \%$ and are predominantly obtained with well annealed, polycrystalline absorber films.

\section{ACKNOWLEDGMENTS}

This research was supported by the Department of Energy Basic Sciences and the Oregon Nano and Microtechnologies Institute. 


\section{REFERENCES}

1. K. Ernst, A. Belaidi, R. Könenkamp, Semicond. Sci. Technol. 18, 475 (2003)

2. W.U. Huynh, J.J. Dittmer, W.C. Libby, G.L. Whiting, A.P. Alivisatos, Advanced Functional Materials 13, 73 (2003)

3. M. Law, L. E. Greene, J. C. Johnson, R. Saykally and P. Yang, Nature Materials 4, 455 (2005)

4. J. B. Baxter and E. S. Aydil, Appl. Phys. Lett. 86, 053114 (2005)

5. C. Lévy-Clément, R. Tena-Zaera, M. A. Ryan, A. Katty, G. Hodes, Advanced Materials 17, $1512(2005)$

6. K. S. Leschkies, R. Divakar, J. Basu, E. Enache-Pommer, J. E. Boercker, C. Barry Carter, U. R. Kortshagen, D. J. Norris, and E. S. Aydil, Nano Lett., 71793 (2007)

7. R. Könenkamp, R. Word and C. Schlegel, Appl. Phys. Lett. 24, 6004 (2004) 